Article

\title{
Interfacial Biocatalytic Performance of Nanofiber-Supported $\beta$-Galactosidase for Production of Galacto-Oligosaccharides
}

\author{
Mailin Misson ${ }^{1,2}{ }^{-}$, Bo Jin ${ }^{2}$, Sheng Dai ${ }^{3}$ and Hu Zhang ${ }^{2,4, *}$ \\ 1 Bioprocess Engineering Research Group, Biotechnology Research Institute, Universiti Malaysia Sabah, Jalan \\ UMS, Kota Kinabalu 88400, Sabah, Malaysia; mailin@ums.edu.my \\ 2 School of Chemical Engineering, University of Adelaide, Adelaide, SA 5000, Australia; \\ bo.jin@adelaide.edu.au \\ 3 School of Chemical Engineering, Brunel University London, Kingston Lane, Uxbridge, \\ Middlesex UB8 3PH, UK; Sheng.Dai@brunel.ac.uk \\ 4 Amgen Bioprocess Centre, Keck Graduate Institute, 535 Watson Drive, Claremont, CA 91711, USA \\ * Correspondence: hu_zhang@kgi.edu
}

Received: 26 November 2019; Accepted: 18 December 2019; Published: 6 January 2020

\begin{abstract}
Molecular distribution, structural conformation and catalytic activity at the interface between enzyme and its immobilising support are vital in the enzymatic reactions for producing bioproducts. In this study, a nanobiocatalyst assembly, $\beta$-galactosidase immobilized on chemically modified electrospun polystyrene nanofibers (PSNF), was synthesized for converting lactose into galacto-oligosaccharides (GOS). Characterization results using scanning electron microscopy (SEM) and fluorescence analysis of fluorescein isothiocyanat (FITC) labelled $\beta$-galactosidase revealed homogenous enzyme immobilization, thin layer structural conformation and biochemical functionalities of the nanobiocatalyst assembly. The $\beta$-galactosidase/PSNF assembly displayed enhanced enzyme catalytic performance at a residence time of around $1 \mathrm{~min}$ in a disc-stacked column reactor. A GOS yield of $41 \%$ and a lactose conversion of $88 \%$ was achieved at the initial lactose concentration of $300 \mathrm{~g} / \mathrm{L}$ at this residence time. This system provided a controllable contact time of products and substrates on the nanofiber surface and could be used for products which are sensitive to the duration of nanobiocatalysis.
\end{abstract}

Keywords: $\beta$-galactosidase; polymer nanofibers; nanobiocatalyst; interfacial characterization; interfacial reaction; conformational change

\section{Introduction}

Nanobiocatalysts synthesized by immobilizing enzyme onto nanocarriers can enhance enzyme stability and activity, and importantly enzyme recycling and reuse ability for industrial bioprocess [1-3]. However, enzymes may encounter structural change upon immobilization due to protein conformation change at the interface, resulting in a reduction of their biocatalytic activity. There are many factors involved in enzyme conformational changes including the features of enzyme molecules and the support material (size and topography), systematic conditions (e.g., $\mathrm{pH}$ and temperature) as well as interaction forces (e.g., polar or hydrophobic/hydrophilic) [4-6]. The functionality and stability of the immobilized enzymes in a bioreactor system remain a major challenge in large scale operation. In addition, the strategies for recovering biocatalysts are also still poorly developed. Hence, a continuous study is highly pursued to develop enzyme supports with robust and separable features while effectively preserving enzyme activity. 
The breakthroughs in nanotechnology and biotechnology have led to immobilization of enzymes on nanostructured materials as a promising approach in enhancing enzyme performances. Nanomaterial carriers allow the creation of a nanoenvironment that favours desirable biochemical kinetics and selectivity of enzyme molecules for maximal reaction efficiencies. We have reported that incorporation of $\beta$-galactosidase on functionalized polystyrene nanofiber can provide a nanoenvironment that favours the enzymatic bioreaction to maximize galacto-oligosaccharide production [7]. Functionalized nanocarriers enable assembling enzyme in an ordered structure besides providing a high enzyme payload attributed by its large surface area [8]. To date, enzymes have been introduced onto various functional nanomaterials including nanofiber scaffolds [9], nanotubes [10], nanoparticles [11], nanocomposites [12] and nanosheets [13] and nanofibers [14].

Recent studies reported that enzymes could be immobilized on various nanofibers made from cellulose polymers [15], polystyrene [7], poly(e-caprolactone) [16], polyaniline [17], chitosan [18], polyethylene oxide [19], polylactic acid [20], and polyacrylonitrile [21]. Nanofiber is fabricated using an electrospinning device, and the size of fibrous mats ranges from nanometers to a few micrometres. Its outstanding characteristics, including high porosity and interconnectivity that reduce mass transfer resistance and a high ratio of surface area to mass that provides a much greater loading capacity, make nanofiber as a promising enzyme carrier. Furthermore, nanofiber provides great opportunities to be applied in a bioreactor system due to its recyclability and specific surface properties with self-assembling behaviour.

We have explored $\beta$-galactosidase on a chemically modified polystyrene nanofiber (PSNF) as nanobiocatalyst ( $\beta$-galactosidase/PSNF) to catalyze bioconversion of lactose in dairy industry wastes into valuable and marketable products, galacto-oligosaccharides (GOSs) [22,23] as GOSs are a high value-added functional food ingredient, offering a range of important health functions in living systems including prebiotic benefits and low-calorie sugar alternatives [24]. The catalytic process by the nanobiocatalyst in the static system [22] resulted in $28 \mathrm{wt} \%$ GOS and a conversion of lactose of $40 \%$, while in a spiral reactor [23], both GOS yield and lactose conversion using the same nanobiocatalyst has been significantly improved. One key factor was found to be the residence time of feed stream on the nanofiber surface: too long GOS was further hydrolysed into glucose and galactose, too short the GOS yield was also reduced. To further control the residence time of products and substrates on the nanofiber, we designed a column bioreactor in which the feed/product stream had a controlled contact time with the nanobiocatalyst. To understand the enzyme-nanofiber interactions, the $\beta$-galactosidase/PSNF nanobiocatalyst was systematically characterized. The nanobiocatalyst performance in the scalable bioreactor for GOS production was evaluated. Correlation between the enzyme conformation structure and its engineering performance was built, which may provide great insights into fabricating other nanobiocatalysts.

\section{Results and Discussion}

\subsection{Textural Properties of Polymer Nanofibers}

It has been recognized that an investigation of protein adsorption on a solid surface is a fascinating endeavour but a great complexity [25]. In comparison to the free enzyme, the presence of enzyme supports, or carriers can complicate both experimental data collections and their theoretical interpretations [4]. Several techniques can provide key information of not only the characteristics of enzyme supports but also of the enzyme distribution on the surface and the interfacial reactions between enzyme and its support. We employed SEM, fluorescence microscopy and Fourier transforms infrared (FTIR) to characterize the prepared nanobiocatalyst.

The chemical characteristics of the nanofibers play an important role in $\beta$-galactosidase binding and enzyme-catalyzed reactions. To introduce functional groups for enzyme immobilisation and tune the nanoenvironment for enzyme reaction, the PSNF surface was treated by concentrated $\mathrm{HNO}_{3}$ $(63 \%)$ for 2,10 and $24 \mathrm{~h}$ to generate oxygen-containing functional groups such as carboxyl $(\mathrm{COOH})$ 
and hydroxyl $(\mathrm{OH})$ to facilitate $\beta$-galactosidase binding [26]. The effect of surface modifications on mechanical stability and wettability of the nanofibers was first examined. Figure 1 indicates that surface modification leads to changes in the surface properties of the nanofiber. Unmodified PSNFs exhibit a smooth surface and a uniform-sized structure (Figure 1a) with a diameter of around $2.25 \pm 0.76 \mu \mathrm{m}$ for a single nanofiber, while surface damages are observed on the acid-treated PSNFs with minor defects for $2 \mathrm{~h}$ modified PSNFs but the dimension is nearly the same as the unmodified PSNFs (Figure 1b). More destructions are found after longer treatment (10 or $24 \mathrm{~h}$ ) (Figure $1 \mathrm{c}-\mathrm{d}$ ) with a rougher surface, more heterogeneous size distribution, some observable small pieces ripped off from the original nanofibers, and size shrinkage of the diameter of a single nanofiber. The $2 \mathrm{~h}$ treated PSNFs were therefore selected for further characterization and investigation in comparison with the untreated PSNFs.
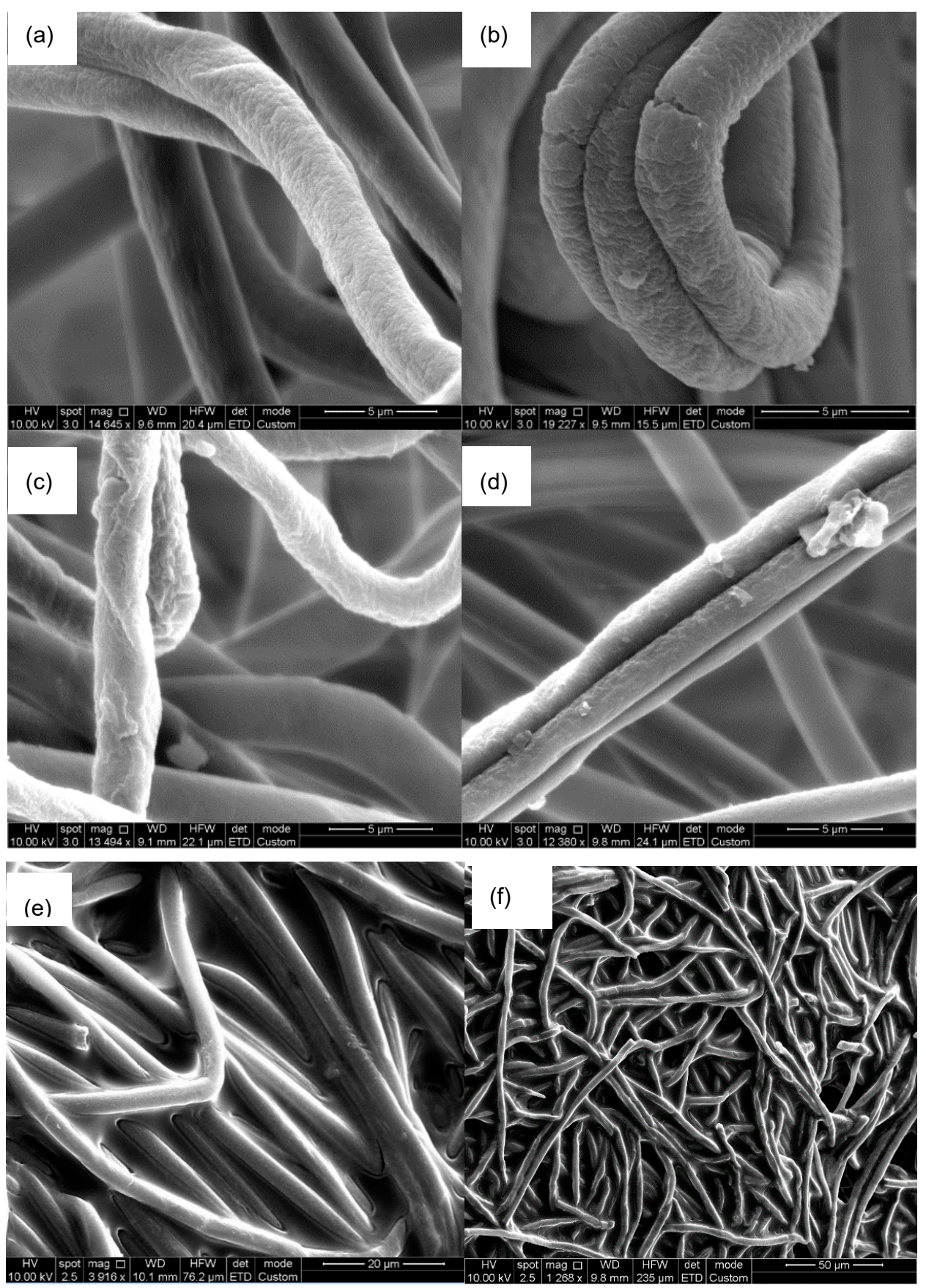

Figure 1. SEM images of (a) untreated, (b) $2 \mathrm{~h}$ acid-treated, (c) $10 \mathrm{~h}$ acid-treated, and (d) $24 \mathrm{~h}$ acid-treated nanofibers, (e) and (f) nanofibers with immobilized enzyme at $20 \mu \mathrm{m}$ and $50 \mu \mathrm{m}$ SEM scale. 


\subsection{Physical Characterization of Nanofibers/ $\beta$-Galactosidase Assembly}

After the nanofibers were treated, they were employed for the preparation of nanobiocatalysts. One of the key issues for the nanobiocatalyst is the distribution of bound proteins on the support nanocarriers. The most common method is to visualize the morphological changes of the nanofibers after enzyme immobilization under an SEM. Alternatively, the molecular distribution can be analysed from fluorescence-assisted images under a fluorescence microscope after the enzyme is tagged with fluorescence molecules [27]. For our nanofiber/ $\beta$-galactosidase hybrids, although minor cracks are noticed on $2 \mathrm{~h}$ treated nanofibers, all enzyme-loading nanofibers have a nearly identical thickness, which means that a thin layer of enzyme coating uniformly covers the PSNF surface (Figure 1e,f at $20 \mu \mathrm{m}$ and $50 \mu \mathrm{m}$ magnification, respectively). This thin layer is formed by the enzyme molecule interaction with functional groups distributed on the nanofiber surface that is characterized by our previous reports $[7,26]$. A similar layer of homogenous antibody coating was recently reported on electrospun polyethersulfone nanofibrous membrane due to hydrophobic interactions [28].

The fluorescence microscope that provides an efficient and unique approach to visualize proteins on various support matrices was also used to further investigate the nanofiber/ $\beta$-galactosidase hybrids. The enzyme was initially labelled with FITC, immobilized onto the PSNF surface afterwards and imaged directly under a fluorescence microscope (Figure 2). PSNFs without enzyme under the same fluorescence conditions were used to account for the fluorescence background (Figure 2a). It is clearly seen from Figure $2 b$ that green fluorescence is emitted from the FITC-labelled $\beta$-galactosidase/PSNF nanobiocatalyst and the green colour is distributed on the entire surface of nanofibers, indicating the presence of homogeneously distributed enzyme on the fibre surface. The observations of enzyme loaded nanocarriers were compared with the negative control of PSNFs- $\beta$-gal without fluorescence excitation as shown in Figure 2c. A similar technique has been applied to reveal the presence of trypsin entrapped in electrospun poly (caprolactone) nanofibers [29].

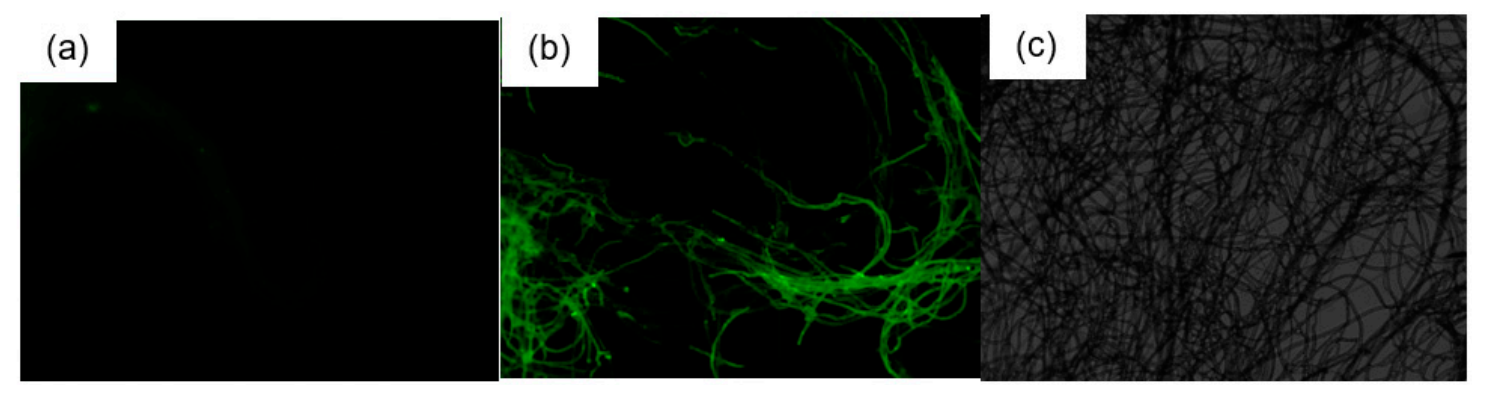

Figure 2. Visualization of FITC-tagged enzyme using fluorescence microscope: (a) PSNF fluorescence background, (b) FITC-PSNF- $\beta$-Gal with fluorescence excitation (c) negative control PSNF- $\beta$-gal without fluorescence excitation.

\subsection{Chemical Characterization of $\beta$-Galactosidase/Nanofibers}

The interaction of $\beta$-galactosidase at the surface of the nanofibers was further clarified using FTIR in Figure 3. The characteristic signals of the $\beta$-galactosidase-free PSNFs are represented by the peaks at $3100,1493,1451,1150,905,754$ and $700 \mathrm{~cm}^{-1}$. It is consistent with the characteristics of polystyrene nanofiber bands which are found at 1602, 1493,1451,1180, 905, 754 and $700 \mathrm{~cm}^{-1}$ as reported by Liang CY [30]. Meanwhile, the $\beta$-galactosidase spectra show the peaks at 3290, 1640, $1405,1310,1230,1100$ and $1050 \mathrm{~cm}^{-1}$. After assembling $\beta$-galactosidase on PSNFs, three new peaks were detected at 3290, 1641 and $1230 \mathrm{~cm}^{-1}$. According to Verma et al. [31], the vibrations of O-H and N-H groups of the enzyme occur between 3000 and $3500 \mathrm{~cm}^{-1}$. Therefore, the peak detected at $3290 \mathrm{~cm}^{-1}$ corresponds to the spectra generated by $\beta$-galactosidase which is absent at the enzyme-free nanofiber. Similarly, the peak at $1641 \mathrm{~cm}^{-1}$ corresponds to $C=O$ stretch vibrations of peptide linkages produced by amide I protein [32], whereas the signal at $1230 \mathrm{~cm}^{-1}$ ascribes to C-N stretching and $\mathrm{N}-\mathrm{H}$ bending. The FTIR analysis demonstrates successful incorporation of $\beta$-galactosidase onto the 
polymer nanofibers. Khoshnevisan, et al. [33] reported a successful binding of cellulase onto $\mathrm{Fe}_{3} \mathrm{O}_{4}$ nanoparticles which were confirmed by the characteristic bands of protein at 1624 , and $1408 \mathrm{~cm}^{-1}$ using the FTIR technique.

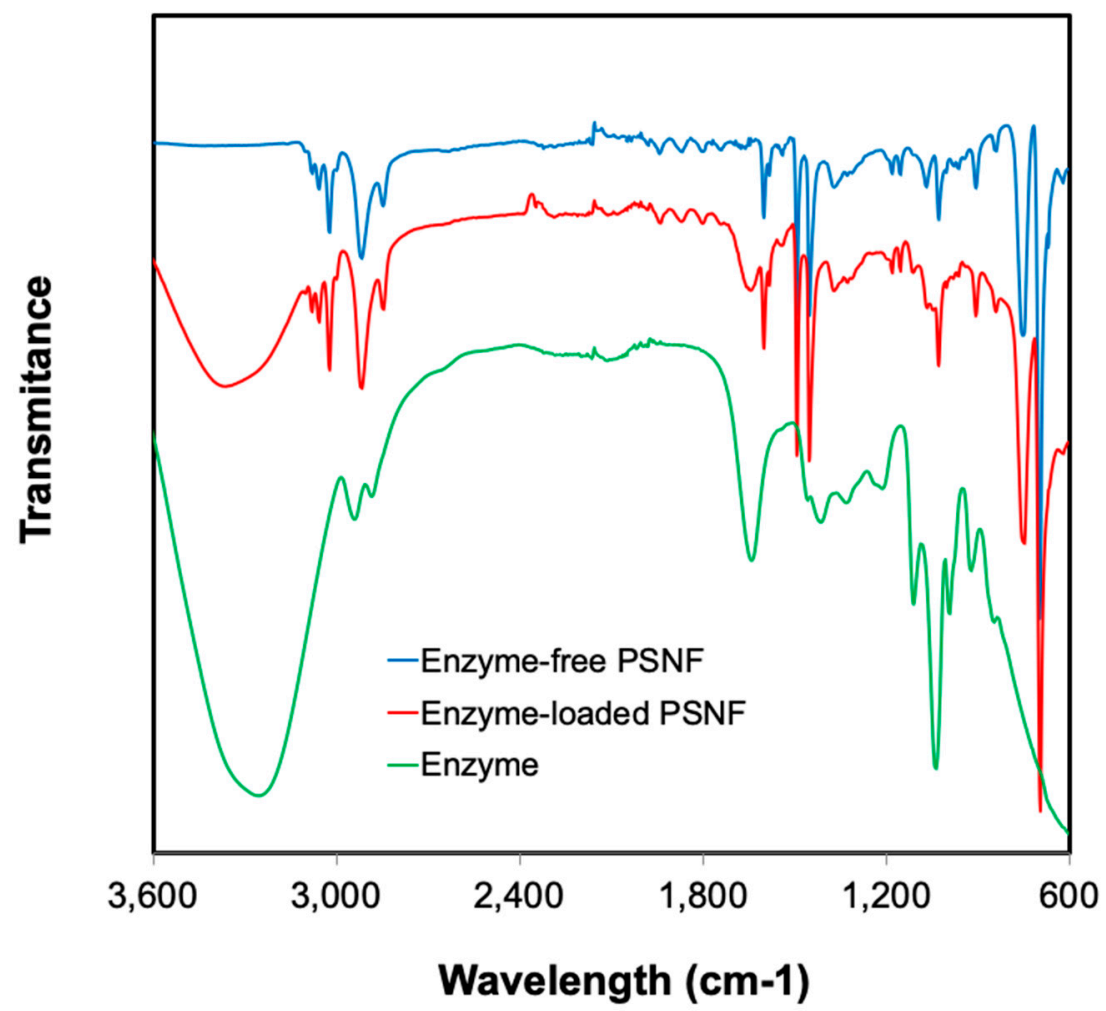

Figure 3. FTIR spectra of enzyme-free PSNF, enzyme-loaded PSNF and free $\beta$-enzyme.

\subsection{Biocatalytic Performance of PSNF- $\beta$-Galactosidase}

The biocatalytic performance of PSNF- $\beta$-galactosidase for GOS production was evaluated in an in-house fabricated recirculating column reactor system. Enzyme-loaded nanofiber sheets were placed inside holders which were stacked on top each other as represented by the schematic diagram of the operation shown in Section 3.5. A pump was used to control the flow rate, the capacity of processing feed streams and the retention time inside the reactor. The recirculation cycle, or also known as the capacity of handling the feed stream, increases as the flow increases while the retention time reduces correspondingly as tabulated in Table 1.

Table 1. Lactose conversion with respect to operation conditions of recirculating column reactor system: feeding flow rate, total recirculation cycle and residence time.

\begin{tabular}{ccc}
\hline Flow Rate (mL/min) & Capacity of Handling Flow Rate Cycle $\left.\mathbf{( h}^{\mathbf{- 1}}\right)$ & Retention Time $(\mathbf{h})$ \\
\hline 2 & 20 & 0.050 \\
4 & 40 & 0.025 \\
6 & 60 & 0.017 \\
8 & 80 & 0.013 \\
10 & 100 & 0.010 \\
\hline
\end{tabular}

In the $\beta$-galactosidase-catalyzed reaction, lactose conversion is generally performed in two different pathways: (1) hydrolysis to glucose and galactose; and (2) transgalactosylation to GOS [34,35]. Hydrolysis occurs when water acts as galactosyl acceptor, yielding glucose and galactose as main products, [36,37]. Meanwhile, sugars such as lactose, glucose and galactose that present in the reaction medium, act as the nucleophiles and become the acceptors to produce GOS in transgalactosylation 
pathway. Therefore, the products from $\beta$-galactosidase-catalyzed reaction include glucose, galactose, GOS and the remaining lactose. GOS comprises of mono and disaccharides with a degree of polymerization of up to 8-9 [38], were determined by the mass balance difference between the initial lactose and the total amount of remaining lactose, glucose and galactose.

The effect of flow rate on lactose conversion and GOS production was systematically investigated throughout the experiments using the recirculating column reactor system. The results are presented in Figure 4 . As the feeding rate increases up to $6 \mathrm{~mL} / \mathrm{min}$, corresponding to a feed rate of $150 \mathrm{~g}$ lactose/h, the lactose conversion reaches up to $80 \%$. The results show that the conversion increases with the increasing the capacity of streams fed into the reactor. A previous study conducted by Kim, et al. [39] showed an enhanced treatment rate of organic pollutants with increased batch cycles. Beyond $6 \mathrm{~mL} / \mathrm{min}$ flow rate, a remarkable reduction in the conversion is observed (Figure 4a). The formation of GOS, glucose and galactose show a similar production profile and trend in Figure $4 \mathrm{~b}$. The highest GOS yield is $145 \mathrm{~g} / \mathrm{L}$ in a trial at a feed rate at $6 \mathrm{~mL} / \mathrm{min}$ flow rate, producing $113 \mathrm{~g} / \mathrm{L}$ glucose and $72 \mathrm{~g} / \mathrm{L}$ galactose.
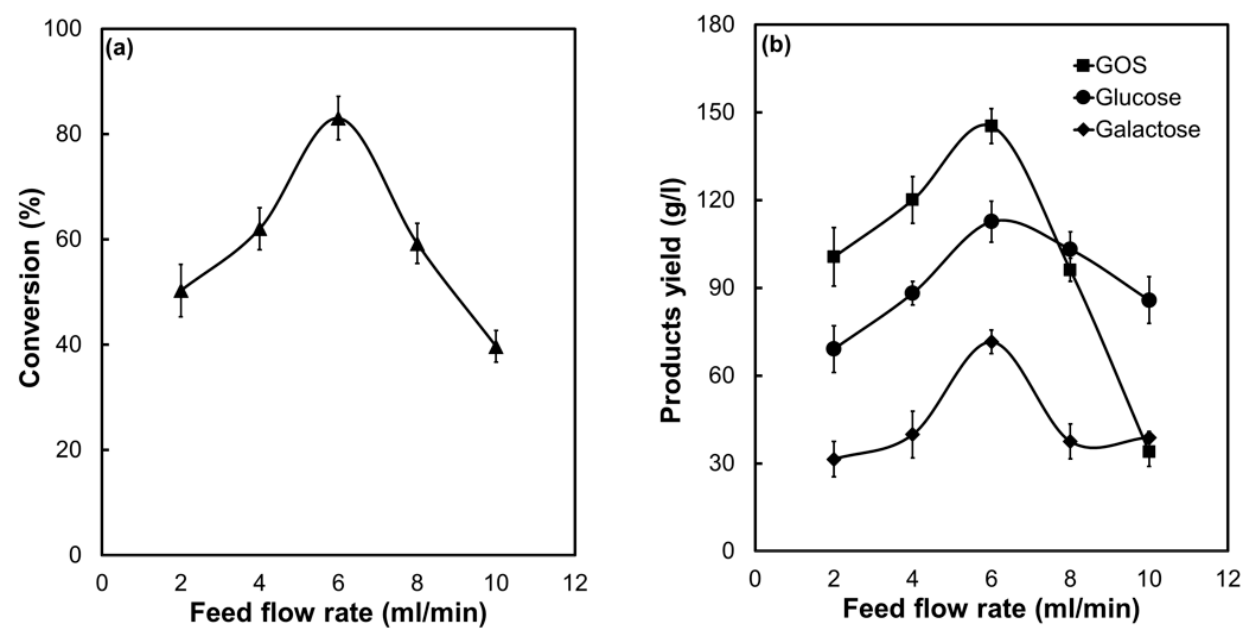

Figure 4. The effect of feed flow rate on (a) lactose conversion and (b) products yield from biocatalysis from immobilized $\beta$-galactosidase on PSNFs in a recirculating column reactor. Reactions were conducted at an initial lactose concentration of $400 \mathrm{~g} / \mathrm{L}$ at $37^{\circ} \mathrm{C}$ with an enzyme concentration of $2 \mathrm{mg} / \mathrm{mL}$ at $\mathrm{pH} 7$ for $24 \mathrm{~h}$ reaction. Triplicate biological samples were prepared and data are shown as mean \pm SD.

It is observed that the GOS yield exceeds that of glucose and galactose when the reactor is operated up to $6 \mathrm{~mL} / \mathrm{min}$ flow rate, or residence time of $1 \mathrm{~min}$ in each unit of the column reactor, implying transgalactosylation is favoured. This is in agreement with our previous study conducted in a recirculating spiral reactor, where enzyme-carrying nanofibers were spread onto mesh support and the mesh was rolled in a spiral form before locating inside a reactor [23]. However, in that spiral reactor, the highest GOS production was accompanied by a reduced lactose conversion. Under the optimal flow rate in this column bioreactor, the highest GOS production and lactose conversion are achieved. Lactose molecules diffuse rapidly into the enzyme reaction sites as the thickness of the concentration boundary layer is reduced. GOS molecules move out of the reaction sites while the $\beta$-galactosidase-galactosyl complexes form in favour of transgalactosylation. Increasing the flow rate up to $10 \mathrm{~mL} / \mathrm{min}$, hydrolysis was found to become the dominated reaction over transgalactosylation that is supported by a drastic decrease in GOS. These observations are likely to be correlated with reduced contact time for interfacial interaction between lactose nucleophiles and enzyme-galactosyl complex, promoting hydrolysis activity to yield glucose and galactose.

The bioconversion and production profile of PSNF- $\beta$-galactosidase with a range of lactose concentrations in the recirculating column reactor are presented in Figure 5. The results reveal that the conversion and product yields are dependent on the initial lactose concentration. A gradual decrease of lactose conversion is found with an increase in the concentration of lactose (Figure 5a). The highest 
lactose conversion $(88 \%)$ is achieved at the initial lactose concentration of $300 \mathrm{~g} / \mathrm{L}$. When the lactose concentration reaches up to $600 \mathrm{~g} / \mathrm{L}$, approximate $80 \%$ of lactose remains unconverted. Longer reaction time is required to catalyse the lactose conversion. It has been recognized that the conversion efficiency is normally determined by the availability of catalytic sites of the immobilized enzyme [23]. Saturation of the enzyme active sites by substrate molecules results in a lower conversion at a higher lactose concentration. Furthermore, lactose at a high concentration is oftentimes associated with low solubility with the presence of crystal-like substances in the reaction medium that reduces the conversion rate [40]. Interestingly, except for $600 \mathrm{~g} / \mathrm{L}$ lactose concentration, the yield of GOS exceeds that of glucose and galactose, indicating the $\beta$-galactosidase/PSNF system favours the desired transgalactosylation at a relatively high lactose concentration in the feed stream (Figure $5 \mathrm{~b}$ ). The highest GOS yield $(160 \mathrm{~g} / \mathrm{L})$ is obtained at an initial lactose concentration of $500 \mathrm{~g} / \mathrm{L}$, which is 1.3 times higher than that of $300 \mathrm{~g} / \mathrm{L}$ lactose concentration.
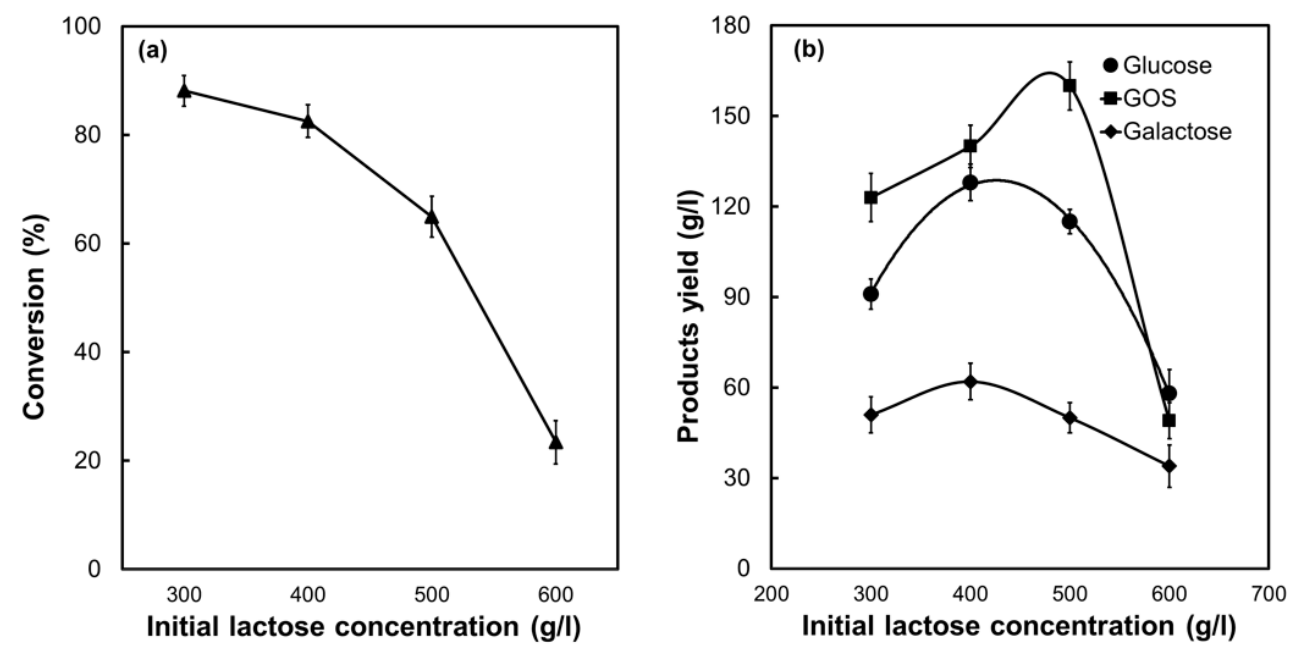

Figure 5. Profiles of (a) lactose conversion and (b) products yield of immobilized $\beta$-galactosidase on PSNF in a recirculating column reactor using lactose at various concentrations. Reactions were conducted on a lactose concentration ranging from 300 to $600 \mathrm{~g} / \mathrm{L}$ at a feed flow rate of $6 \mathrm{~mL} / \mathrm{min}$, using $2 \mathrm{mg} / \mathrm{mL}$ enzyme concentration at $37^{\circ} \mathrm{C}$ at $\mathrm{pH} 7$ for $24 \mathrm{~h}$ reaction. Triplicate biological samples were prepared and data are shown as mean \pm SD.

Overall, the nanobiocatalyst of PSNF- $\beta$-galactosidase shows an excellent catalytic performance in the recirculating column reactor for conversion of lactose-rich dairy wastes into valuable products. The bioconversion performance using PSNF- $\beta$-galactosidase is also comparable or greater than that in other reported studies as briefed in Table 2. It can be concluded that the interface from the nanofiber and the newly developed PSNF-Gal recirculating column reactor provide favourable nanoenvironments that maximize the biocatalytic performance. More importantly, comparing to static feed as reported in our previous study [7], the process in the recirculating column bioreactor enhances the lactose bioconversion from $40 \%$ to $88 \%$ and the GOS yield from 110 to $160 \mathrm{~g} / \mathrm{L}$. The superiority of the disc reactor in this study was further demonstrated by its higher yield per area than that in the spiral reactor. For example, at an initial substrate concentration of $300 \mathrm{~g} / \mathrm{L}$, the yield per area in the disc reactor is $4.17 \mathrm{~g} / \mathrm{L} \mathrm{cm}^{-2}$, approximately 4.3 times higher than that in the spiral reactor $\left(0.33 \mathrm{~g} / \mathrm{L} \mathrm{cm}^{-2}\right)$. Hence, the disc reactor may be further optimized for an industrial process. 
Table 2. Comparison on lactose bioconversion and GOS yield by immobilized enzymes in various types of support materials.

\begin{tabular}{|c|c|c|c|c|c|c|}
\hline $\begin{array}{c}\text { Source of } \\
\beta \text {-Galactosidase }\end{array}$ & Reactor & Support Material & Lactose & Conversion & GOS & Reference \\
\hline- & - & - & $\mathrm{g} / \mathrm{L}$ & $\%$ & $\%$ & - \\
\hline \multirow{2}{*}{$\begin{array}{c}\text { Kluyveromyces } \\
\text { lactis }\end{array}$} & \multirow{2}{*}{ Disc reactor } & \multirow{2}{*}{$\begin{array}{l}\text { Polystyrene } \\
\text { nanofibers }\end{array}$} & 300 & 88 & 41 & This work \\
\hline & & & 400 & 83 & 35 & This work \\
\hline \multirow{2}{*}{$\begin{array}{l}\text { Kluyveromyces } \\
\text { lactis }\end{array}$} & \multirow{2}{*}{ Spiral reactor } & \multirow{2}{*}{$\begin{array}{l}\text { Polystyrene } \\
\text { nanofibers }\end{array}$} & 300 & 86 & 31 & [38] \\
\hline & & & 400 & 86 & 40 & [38] \\
\hline \multirow{2}{*}{$\begin{array}{c}\text { Kluyveromyces } \\
\text { lactis }\end{array}$} & \multirow{2}{*}{ Batch process } & \multirow{2}{*}{$\begin{array}{l}\text { Polystyrene } \\
\text { nanofibers }\end{array}$} & 300 & 38 & 20 & [41] \\
\hline & & & 400 & 40 & 28 & {$[41]$} \\
\hline $\begin{array}{c}\text { Kluyveromyces } \\
\text { lactis }\end{array}$ & $\begin{array}{l}\text { Continuous } \\
\text { ultrafiltration } \\
\text { membrane } \\
\text { reactor }\end{array}$ & Membrane & 300 & 76 & 80 & [42] \\
\hline Bacillus circulans & $\begin{array}{l}\text { Repetitive } \\
\text { batch-wise }\end{array}$ & Eupergit C250L & 550 & - & 64 & [43] \\
\hline Bacillus circulans & Repeated batch & Glyoxyl agarose & 500 & 60 & 39 & [44] \\
\hline Bacillus circulans & Batch process & - & 400 & 50 & 41 & [45] \\
\hline $\begin{array}{c}\text { Aspergillus } \\
\text { oryzae }\end{array}$ & Batch process & $\begin{array}{c}\text { Polysiloxane- } \\
\text { polyvinyl alcohol }\end{array}$ & 500 & 55 & 26 & [46] \\
\hline
\end{tabular}

\section{Materials and Methods}

\subsection{Materials}

Polystyrene (MW 350,000), N,N-dimethylformamide (DMF), nitric acid $\left(\mathrm{HNO}_{3}\right), 69 \%$, Fluorescein isothiocyanate (FITC), bovine serum albumin (BSA) and Kluyveromyces lactis $\beta$-galactosidase were purchased from Sigma-Aldrich (St. Louis, MO, USA). Lactose monohydrate was from Chem Supply and potassium phosphate buffer (PBS, pH 7.2) was from Life Technologies (Carlsbad, CA, USA).

\subsection{Synthesis of Polymer Nanofibers}

Polystyrene $(20 \%, w / v)$ was prepared by dissolving in DMF in a flask stirring at $100 \mathrm{rpm}$ for overnight at room temperature. The solution was then transferred to a $5 \mathrm{~mL}$ syringe of electrospinning device, and the syringe was attached to a $1 \mathrm{~mm}$ inner diameter needle tip which was connected to a Glassman high voltage power supply $(25 \mathrm{kV})$. The flow rate of the polymer solution was controlled at $2.5 \mathrm{~mL} / \mathrm{h}$ by an Adelab Scientific syringe pump. The electrospun PSNFs were cast onto a metal-surface collector, and the distance between the needle tip and the collector was fixed at $10 \mathrm{~cm}$. After electrospinning, the PSNFs were detached from the collector surface and stored at room temperature for further use.

\subsection{Nanofibers Modification and $\beta$-Galactosidase Immobilization}

The surface of PSNFs was further treated by oxidation in acid. In detail, 20-30 mg PSNFs were immersed into $5 \mathrm{~mL} \mathrm{HNO}_{3}(69 \%)$ for $2 \mathrm{~h}$ at room temperature [7]. After surface treatment, the PSNFs were rinsed with water three times to remove excess acid and then equilibrated with PBS ( $\mathrm{pH}$ 7.2) overnight prior to enzyme immobilization. $\beta$-galactosidase immobilization was carried out by submerging the treated approximately $10 \mathrm{mg}$ PSNFs into $1 \mathrm{~mL} \beta$-galactosidase PBS solution $(2 \mathrm{mg} / \mathrm{mL})$ overnight with gentle stirring at $4{ }^{\circ} \mathrm{C}$. The $\beta$-galactosidase-loading PSNFs were rinsed thoroughly with water to remove unbound enzyme.

\subsection{Characterization of Nanobiocatalyst}

The textural and morphological properties of PSNF, $\beta$-galactosidase and $\beta$-galactosidase-loaded PSNFs were characterized by a Philips XL30 field emission scanning electron microscope (FESEM) 
operated at $10 \mathrm{kV}$. A Zeiss Axio fluorescence microscope was used to image the distribution of FITC-labelled $\beta$-galactosidase on nanofiber surfaces. The enzyme was initially labelled using FITC dye and it was prepared by mixing $100 \mathrm{mg}$ of $\beta$-galactosidase with $10 \mu \mathrm{g}$ of FITC in $1 \mathrm{~mL}$ ethanol $(70 \%)$ solution with gentle mixing before the addition of PSNF. The FITC-tagged $\beta$-galactosidase on PSNF was allowed to react for $2 \mathrm{~h}$ at $4{ }^{\circ} \mathrm{C}$ in dark before observation under a fluorescence microscope. Fourier transforms infrared (FTIR) spectra of free $\beta$-galactosidase, PSNF, and PSNF- $\beta$-galactosidase were recorded on a Thermo Scientific NICOLET 6700 FTIR spectrometer at room temperature.

\subsection{Experimental Set-Up of a Recirculating Column Reactor}

The bioengineering performance of PSNF- $\beta$-galactosidase was further assessed in an in-house recirculating column reactor (RCR). The RCR system comprises a reservoir tank maintained at $37^{\circ} \mathrm{C}$ using a water bath, a Masterflex 7021-24 pump to control the feed flow rate, and a column reactor containing enzyme-loading nanofiber sheets fitted into a holder ( $25 \mathrm{~mm}$, Waterman) which were stacked on top of each other to form a 12-cm height column with a total working volume of $6 \mathrm{~mL}$. The schematic diagram of the RCR system is illustrated in Figure 6. Eur-Pharm silicone tubing was used to connect the reservoir tank to the column reactor. Lactose solution in the feed reservoir was prepared by dissolving lactose into PBS ( $\mathrm{pH}$ 7.2). The solution was fed from the bottom inlet of the reactor using a peristaltic pump and passed through the RCR containing immobilized $\beta$-galactosidase on PSNF and returned back into the feed reservoir through the top outlet. Variable operation parameters including flow rate $(2-10 \mathrm{~mL} / \mathrm{min})$ and lactose initial concentration $(300-600 \mathrm{~g} / \mathrm{L})$ were evaluated to optimize the GOS production. The capacity of handling feed per hour and the retention time inside the reactor, as calculated using Equations (1) and (2) respectively, was determined by the flow rate.

$$
\text { Capacity of handling feed per hour }\left(\mathrm{h}^{-1}\right)=\frac{\text { Flow rate }(\mathrm{ml} / \mathrm{min})}{\text { Feed working volume }(\mathrm{ml})} \times 60
$$

$$
\text { Retention time }(\mathrm{h})=\frac{\text { Reactor volume }(\mathrm{ml})}{\text { Flow rate }(\mathrm{ml} / \mathrm{min})} \times \frac{1}{60}
$$
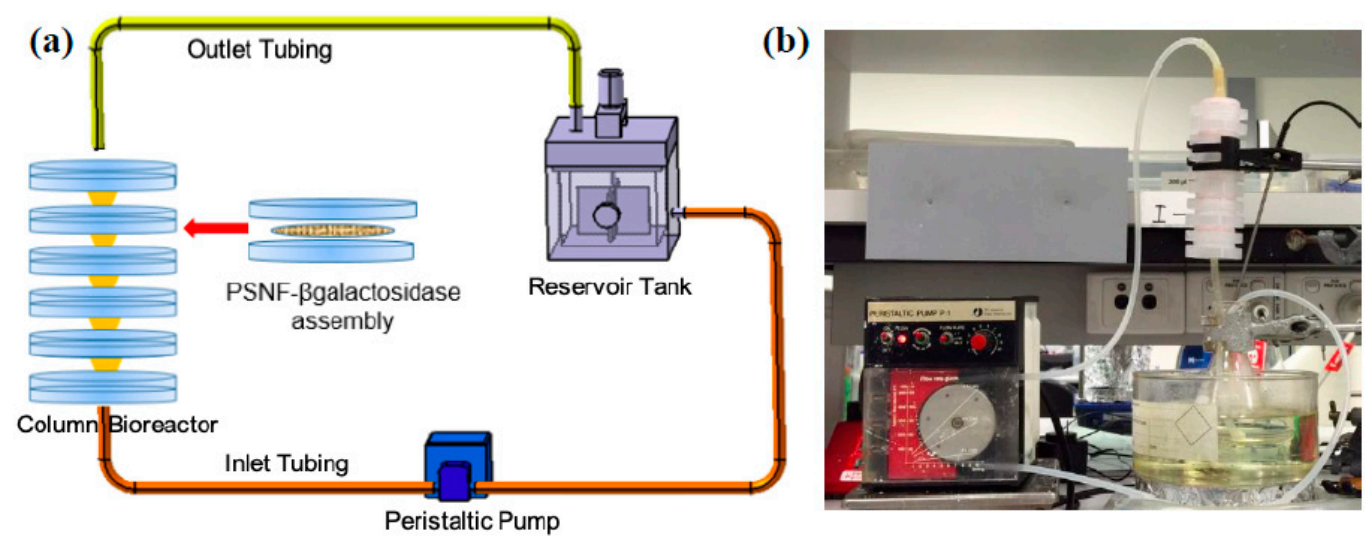

Figure 6. (a) Schematic diagram of a recirculating column reactor for lactose bioconversion using a PSNF- $\beta$-galactosidase system. (b) Actual setup of recirculating column reactor.

The conversion and the yield of glucose, galactose, and GOSs were determined using Equations (2)-(5), where brackets represent mass concentration.

$$
\text { Conversion }(\%)=\frac{[\text { Initial lactose }]-[\text { Final lactose }]}{[\text { Initial lactose }]} \times 100 \%
$$




$$
\begin{gathered}
\text { Glucose }(\%)=\frac{[\text { Glucose }]}{[\text { Initial Lactose }]} \times 100 \% \\
\text { Galactose }(\%)=\frac{[\text { Galactose }]}{[\text { Initial Lactose }]} \times 100 \% \\
\text { GOS }(\%)=\% \text { conversion }-\% \text { glucose }-\% \text { galactose }
\end{gathered}
$$

\subsection{Chemical Analysis}

Filtered substrates and products were analysed by an Agilent 1100 Series HPLC equipped with an Aminex HPX-87H column $(300 \times 7.8 \mathrm{~mm})$ and a refractive index detector The flow rate of pre-degassed mobile phase $\left(8 \mathrm{mmol} / \mathrm{L}-\mathrm{H}_{2} \mathrm{SO}_{4}\right)$ was set to $0.5 \mathrm{~mL} / \mathrm{min}$. The column and the detector cell were maintained at $60^{\circ} \mathrm{C}$ and $40{ }^{\circ} \mathrm{C}$ [41]. Chromatograms were integrated using the ChemStation software.

\section{Conclusions}

A comprehensive analysis study has been carried out to advance the understanding of $\beta$-galactosidase/nanofiber nanobiocatalyst structure. The homogenous biocatalyst distribution on the support surface was demonstrated by SEM and fluorescence microscopy images. The FTIR confirmed successful biocatalyst attachment on the PSNF surface and the native structures of biocatalyst were retained after the formation of the nanobiocatalyst. The nanocatalyst in a column bioreactor had the highest lactose conversion and GOS production at a flow rate of $6 \mathrm{~mL} / \mathrm{min}$, or residence time of $1 \mathrm{~min}$. However, both GOS production and lactose conversion were dependent on the initial lactose concentration, a lower concentration for higher conversion and a higher concentration for a higher GOS yield. Further optimization of this system will be conducted to maximize the GOS production and improve the lactose conversion.

Author Contributions: Formal Analysis, M.M.; Investigation, M.M.; Writing-Original Draft Preparation, M.M.; Writing-Review \& Editing, M.M., H.Z., S.D.; Supervision, B.J., S.D. and H.Z.; Project Administration, M.M.; Funding Acquisition, B.J., S.D. and H.Z. All authors have read and agreed to the published version of the manuscript.

Funding: M.M. gratefully acknowledges the financial support from the Universiti Malaysia Sabah and the Malaysian Government. H.Z. acknowledges funding support from University of Adelaide.

Acknowledgments: The HPLC facility support from Paul Grbin's research group and sugar analysis assistance by Nick Van Holst, analytical supports by Qiuhong Hu at Analytical Lab School of Chemical Engineering, and the SEM analysis from Adelaide Microscope are highly appreciated.

Conflicts of Interest: The authors declare no conflict of interest.

\section{References}

1. Aissaoui, N.; Landoulsi, J.; Bergaoui, L.; Boujday, S.; Lambert, J.-F. Catalytic activity and thermostability of enzymes immobilized on silanized surface: Influence of the crosslinking agent. Enzym. Microb. Technol. 2013, 52, 336-343. [CrossRef] [PubMed]

2. Deng, M.; Zhao, H.; Zhang, S.; Tian, C.; Zhang, D.; Du, P.; Liu, C.; Cao, H.; Li, H. High catalytic activity of immobilized laccase on core-shell magnetic nanoparticles by dopamine self-polymerization. J. Mol. Catal. B Enzym. 2015, 112, 15-24. [CrossRef]

3. He, T.; Tian, Y.-L.; Qi, L.; Zhang, J.; Zhang, Z.-Q. Improved performance of $\alpha$-amylase immobilized on poly (glycidyl methacrylate-co-ethylenedimethacrylate) beads. Int. J. Biol. Macromol. 2014, 65, 492-499. [CrossRef] [PubMed]

4. Secundo, F. Conformational changes of enzymes upon immobilisation. Chem. Soc. Rev. 2013, 42, 6250-6261. [CrossRef]

5. Ba, O.M.; Hindie, M.; Marmey, P.; Gallet, O.; Anselme, K.; Ponche, A.; Duncan, A.C. Protein covalent immobilization via its scarce thiol versus abundant amine groups: Effect on orientation, cell binding domain exposure and conformational lability. Colloids Surf. B Biointerfaces 2015, 134, 73-80. [CrossRef] [PubMed] 
6. Zhuang, W.; Zhang, Y.; Zhu, J.; An, R.; Li, B.; Mu, L.; Ying, H.; Wu, J.; Zhou, J.; Chen, Y.; et al. Influences of geometrical topography and surface chemistry on the stable immobilization of adenosine deaminase on mesoporous $\mathrm{TiO}_{2}$. Chem. Eng. Sci. 2016, 139, 142-151. [CrossRef]

7. Misson, M.; Dai, S.; Jin, B.; Chen, B.H.; Zhang, H. Manipulation of nanofiber-based $\beta$-galactosidase nanoenvironment for enhancement of galacto-oligosaccharide production. J. Biotechnol. 2016, 222, 56-64. [CrossRef]

8. Husain, Q.; Ansari, S.A.; Alam, F.; Azam, A. Immobilization of Aspergillus oryzae $\beta$ galactosidase on zinc oxide nanoparticles via simple adsorption mechanism. Int. J. Biol. Macromol. 2011, 49, 37-43. [CrossRef]

9. Du Plessis, D.M.; Botes, M.; Dicks, L.M.T.; Cloete, T.E. Immobilization of commercial hydrolytic enzymes on poly (acrylonitrile) nanofibers for anti-biofilm activity. J. Chem. Technol. Biotechnol. 2012, 88, 585-593. [CrossRef]

10. Wang, L.; Jiang, R. Reversible His-tagged enzyme immobilization on functionalized carbon nanotubes as nanoscale biocatalyst. Methods Mol. Biol. 2011, 743, 95-106.

11. Johnson, P.A.; Park, H.J.; Driscoll, A.J. Enzyme nanoparticle fabrication: Magnetic nanoparticle synthesis and enzyme immobilization. In Enzyme Stabilization and Immobilization Methods in Molecular Biology; Minteer, S.D., Ed.; Hanna Publisher: Shallowater, TX, USA, 2011; Volume 679, pp. 183-191.

12. Tran, D.T.; Chen, C.L.; Chang, J.S. Immobilization of Burkholderia sp. lipase on a ferric silica nanocomposite for biodiesel production. J. Biotechnol. 2012, 158, 112-119. [CrossRef] [PubMed]

13. Ma, Y.-X.; Li, Y.-F.; Zhao, G.-H.; Yang, L.-Q.; Wang, J.-Z.; Shan, X.; Yan, X. Preparation and characterization of graphite nanosheets decorated with $\mathrm{Fe}_{3} \mathrm{O}_{4}$ nanoparticles used in the immobilization of glucoamylase. Carbon 2012, 50, 2976-2986. [CrossRef]

14. Misson, M.; Zhang, H.; Jin, B. Nanobiocatalyst advancements and bioprocessing applications. J. R. Soc. Interface 2015, 12, 1-8. [CrossRef] [PubMed]

15. Je, H.H.; Noh, S.; Hong, S.-G.; Ju, Y.; Kim, J.; Hwang, D.S. Cellulose nanofibers for magnetically-separable and highly loaded enzyme immobilization. Chem. Eng. J. 2017, 323, 425-433. [CrossRef]

16. Canbolat, M.F.; Savas, H.B.; Gultekin, F. Enzymatic behavior of laccase following interaction with $\gamma$-CD and immobilization into PCL nanofibers. Anal. Biochem. 2017, 528, 13-18. [CrossRef] [PubMed]

17. Ghosh, S.; Chaganti, S.R.; Prakasham, R.S. Polyaniline nanofiber as a novel immobilization matrix for the anti-leukemia enzyme L-asparaginase. J. Mol. Catal. B Enzym. 2012, 74, 132-137. [CrossRef]

18. Maryšková, M.; Ardao, I.; García-González, C.A.; Martinová, L.; Rotková, J.; Ševců, A. Polyamide 6/chitosan nanofibers as support for the immobilization of Trametes versicolor laccase for the elimination of endocrine disrupting chemicals. Enzym. Microb. Technol. 2016, 89, 31-38. [CrossRef]

19. Dorraki, N.; Safa, N.N.; Jahanfar, M.; Ghomi, H.; Ranaei-Siadat, S.-O. Surface modification of chitosan/PEO nanofibers by air dielectric barrier discharge plasma for acetylcholinesterase immobilization. Appl. Surf. Sci. 2015, 349, 940-947. [CrossRef]

20. Silva, T.R.; Rodrigues, D.P.; Rocha, J.M.S.; Gil, M.H.; Pinto, S.C.S.; Lopes-da-Silva, J.A.; Guiomar, A.J. Immobilization of trypsin onto poly(ethylene terephthalate)/poly(lactic acid) nonwoven nanofiber mats. Biochem. Eng. J. 2015, 104, 48-56. [CrossRef]

21. Taheran, M.; Naghdi, M.; Brar, S.K.; Knystautas, E.J.; Verma, M.; Surampalli, R.Y. Degradation of chlortetracycline using immobilized laccase on Polyacrylonitrile-biochar composite nanofibrous membrane. Sci. Total Environ. 2017, 605-606, 315-321. [CrossRef]

22. Misson, M.; Jin, B.; Chen, B.; Zhang, H. Enhancing enzyme stability and metabolic functional ability of $\beta$-galactosidase through functionalized polymer nanofiber immobilization. Bioprocess Biosyst. Eng. 2015, 38, 1915-1923. [CrossRef]

23. Misson, M.; Jin, B.; Zhang, H. Recirculating spiral bioreactor for galactooligosaccharide production using polymer nanofiber- $\beta$-galactosidase assembly. Ind. Eng. Chem. Res. 2017, 56, 12479-12487. [CrossRef]

24. Ganzle, M.G. Enzymatic synthesis of galacto-oligosaccharides and other lactose derivatives (hetero-oligosaccharides) from lactose. Int. Dairy J. 2012, 22, 116-122. [CrossRef]

25. Rabe, M.; Verdes, D.; Seeger, S. Understanding protein adsorption phenomena at solid surfaces. Adv. Colloid Interface Sci. 2011, 162, 87-106. [CrossRef]

26. An, H.; Jin, B.; Dai, S. Fabricating polystyrene fiber-dehydrogenase assemble as a functional biocatalyst. Enzym. Microb. Technol. 2015, 68, 15-22. [CrossRef]

27. Bolivar, J.M.; Eisl, I.; Nidetzky, B. Advanced characterization of immobilized enzymes as heterogeneous biocatalysts. Catal. Today 2016, 259, 66-80. [CrossRef] 
28. Mahmoudifard, M.; Soudi, S.; Soleimani, M.; Hosseinzadeh, S.; Esmaeili, E.; Vossoughi, M. Efficient protein immobilization on polyethersolfone electrospun nanofibrous membrane via covalent binding for biosensing applications. Mater. Sci. Eng. C 2016, 58, 586-594. [CrossRef]

29. Pinto, S.C.; Rodrigues, A.R.; Saraiva, J.A.; Lopes-da-Silva, J.A. Catalytic activity of trypsin entrapped in electrospun poly ( $\epsilon$-caprolactone) nanofibers. Enzym. Microb. Technol. 2015, 79-80, 8-18. [CrossRef]

30. Liang, C.Y.; Krimm, S. Infrared spectra of high polymers. VI. Polystyrene. J. Polym. Sci. 1958, 27, 241-254. [CrossRef]

31. Verma, M.L.; Barrow, C.J.; Kennedy, J.F.; Puri, M. Immobilization of beta-D-galactosidase from Kluyveromyces lactis on functionalized silicon dioxide nanoparticles: Characterization and lactose hydrolysis. Int. J. Biol. Macromol. 2012, 50, 432-437. [CrossRef]

32. Kong, J.; Yu, S. Fourier transform infrared spectroscopic analysis of protein secondary structures. Acta Biochim. Biophys. Sin. 2007, 39, 549-559. [CrossRef]

33. Khoshnevisan, K.; Bordbar, A.K.; Zare, D.; Davoodi, D.; Noruzi, M.; Barkhi, M.; Tabatabaei, M. Immobilization of cellulase enzyme on superparamagnetic nanoparticles and determination of its activity and stability. Chem. Eng. J. 2011, 171, 669-673. [CrossRef]

34. Shen, Q.; Yang, R.; Hua, X.; Ye, F.; Wang, H.; Zhao, W.; Wang, K. Enzymatic synthesis and identification of oligosaccharides obtained by transgalactosylation of lactose in the presence of fructose using beta-galactosidase from Kluyveromyces lactis. Food Chem. 2012, 135, 1547-1554. [CrossRef] [PubMed]

35. Gaur, R.; Pant, H.; Jain, R.; Khare, S.K. Galacto-oligosaccharide synthesis by immobilized Aspergillus oryzae b-galactosidase. Food Chem. 2006, 97, 426-430. [CrossRef]

36. Jovanovic-Malinovska, R.; Fernandes, P.; Winkelhausen, E.; Fonseca, L. Galacto-oligosaccharides synthesis from lactose and whey by beta-galactosidase immobilized in PVA. Appl. Biochem. Biotechnol. 2012, 168, 1197-1211. [CrossRef]

37. Thenmozhi, S.; Dharmaraj, N.; Kadirvelu, K.; Kim, H.Y. Electrospun nanofibers: New generation materials for advanced applications. Mater. Sci. Eng. B 2017, 217, 36-48. [CrossRef]

38. Hernández, O.; Ruiz-Matute, A.I.; Olano, A.; Moreno, J.F.; LuzSanz, M. Comparison of fractionation techniques to obtain prebiotic galactooligosaccharides. Int. Dairy J. 2009, 19, 531-536. [CrossRef]

39. Kim, J.; Lee, S.; Lee, C. Comparative study of changes in reaction profile and microbial community structure in two anaerobic repeated-batch reactors started up with different seed sludges. Bioresour. Technol. 2013, 129, 495-505. [CrossRef]

40. Machado, J.; Coutinho, J.; Maceso, E. Solid-liquid equilibrium of a-lactose in ethanol/water. Fluid Phase Equilib. 2000, 173, 121-134. [CrossRef]

41. Zheng, P.; Yu, H.; Sun, Z.; Ni, Y.; Zhang, W.; Fan, Y.; Xu, Y. Production of galacto-oligosaccharides by immobilized recombinant beta-galactosidase from Aspergillus candidus. Biotechnol. J. 2006, 1, 1464-1470. [CrossRef]

42. Ren, H.; Fei, J.; Shi, X.; Zhao, T.; Cheng, H.; Zhao, N.; Chen, Y.; Ying, H. Continuous ultrafiltration membrane reactor coupled with nanofiltration for the enzymatic synthesis and purification of galactosyl-oligosaccharides. Sep. Purif. Technol. 2015, 144, 70-79. [CrossRef]

43. Benjamins, E.; Boxem, L.; KleinJan-Noeverman, J.; Broekhuis, T.A. Assessment of repetitive batch-wise synthesis of galacto-oligosaccharides from lactose slurry using immobilised $\beta$-galactosidase from Bacillus circulans. Int. Dairy J. 2014, 38, 160-168. [CrossRef]

44. Urrutia, P.; Mateo, C.; Guisan, J.M.; Wilson, L.; Illanes, A. Immobilization of Bacillus circulans $\beta$-galactosidase and its application in the synthesis of galacto-oligosaccharides under repeated-batch operation. Biochem. Eng. J. 2013, 77, 41-48. [CrossRef]

45. Rodriguez-Colinas, B.; Poveda, A.; Jimenez-Barbero, J.; Ballesteros, A.O.; Plou, F.J. Galacto-oligosaccharide synthesis from lactose solution or skim milk using the $\beta$-galactosidase from Bacillus circulans. J. Agric. Food Chem. 2012, 60, 6391-6398. [CrossRef]

46. Neri, D.F.M.; Balcao, V.M.; Costa, R.S.; Rocha, I.C.A.P.; Ferreira, E.M.F.C.; Torres, D.P.M.; Rodrigues, L.R.M.; Carvalho, L.B., Jr.; Teixeira, J.A. Galacto-oligosaccharides production during lactose hydrolysis by free Aspergillus oryzae b-galactosidase and immobilized on magnetic polysiloxane-polyvinyl alcohol. Food Chem. 2009, 115, 92-99. [CrossRef]

(C) 2020 by the authors. Licensee MDPI, Basel, Switzerland. This article is an open access article distributed under the terms and conditions of the Creative Commons Attribution (CC BY) license (http://creativecommons.org/licenses/by/4.0/). 